\title{
Myös aikuiset tarvitsevat tukea oppimisvaikeuksiin
}

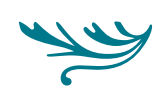

\begin{abstract}
Kuntoutussäätiö toteutti vuosina 2006-2010 Opi oppimaan -projektin, jossa kehitettiin uusia palveluja oppimisvaikeuksista kärsiville aikuisille ja nuorille. Artikkelissa esitellään projektista saatuja kokemuksia aikuisten tukitarpeista ja tehdään kehittämisehdotuksia. Hanke kuului RAY:n oppimisvaikeusohjelmaan.
\end{abstract}

ARTIKKELIN TAUSTANA ON Opi oppimaan -hankkeen arviointitutkimus, jonka tavoitteena oli tuottaa tietoa aikuisten oppimisvaikeuksiin liittyvistä kuntoutustarpeista eri asiakasryhmillä ja tukipalveluista koetuista hyödyistä. Arviointitutkimuksen pääaineistona olivat asiakkaiden alku- $(\mathrm{n}=143)$ ja seurantakyselyt $(n=87)$ sekä yksilö- $(n=26)$ ja ryhmähaastattelut $(\mathrm{n}=10)$. Myös ammattilaisten kokemuksia kartoitettiin (Korkeamäki ym. 2010.) Lisäksi selvitettiin haastatteluaineiston avulla aikuisten kokemuksia oppimisvaikeuksien kanssa selviytymisestä, selviytymiskeinoista ja tuen saamisesta (Korkeamäki 2010a).

\section{AIKUISTEN OPPIMISVAIKEUDET}

Oppimisvaikeudet voidaan ymmärtää tietynlaiseksi sateenvarjokäsitteeksi, jolla viitataan vaikeuksiin lukemisessa, kirjoittamisessa, puhutussa kielessä ja matematiikassa. Kehityksellisistä oppimisvaikeuksista yleisin on lukemisen erityisvaikeus eli dysleksia. Dysleksian kansainväliseen konsensusmääritelmään sisältyy olettamus vaikeuden neurobiologisesta taustasta sekä kielen äännerakennetta koskevasta fonologisen taidon ongelmasta, joka ei ole odotuksenmukainen suhteessa muihin kognitiivisiin kykyihin tai saatuun kouluopetukseen. Dysleksian toissijaisena seurauksena voi olla vähäinen lukeminen, mikä voi haitata sanavaraston ja taustatietomäärän kasvua. (Holopainen ym. 2008, 14-15.) Oppimisvaikeuksien yhteydessä myös muiden vaikeuksien esiintyminen samanaikaisesti on tavallista. Käytännössä se tarkoittaa useiden erityisvaikeuksien tai tarkkaavuushäiriöiden esiintymistä yhdessä. Tavallisimmin yhdessä esiintyvät lukemis- ja kirjoittamisvaikeudet, jonka vuoksi niitä Suomessa kutsutaankin lukivaikeudeksi.

Pitkittäistutkimukset ovat osoittaneet dysleksiaan liittyvien piirteiden olevan suhteellisen pysyviä, samoin kuin lukemiskykyyn liittyvät suhteelliset erot hyvien ja heikkojen lukijoiden välillä. On myös viitteitä siitä, että erot voivat myös kasvaa aikuistuessa. Oppimisvaikeuksien varhainen tunnistaminen ja ennaltaehkäisevät toimet eivät siten poista kaikkia oppimisvaikeuksia, vaan osa lapsista tarvitsee jatkossakin muita enemmän tukea oppimisessa. (Shaywitz \& Shaywitz 2003; Holopainen ja Savolainen 2005). Selkeän lukivaikeuden tai oppimishäiriön ohella puhutaan joko osin tai lähes kokonaan kompensoituneista oppimisvaikeuksista, jolloin lukeminen ja kirjoittaminen voivat sujua hyvin ja yksilö on oppinut käyttämään erilaisia opiskelustra- 
tegioita menestyksekkäästi. Monissa tutkimuksissa on kuitenkin osoitettu, että vaikeudet käsitellä kielen äännerakennetta (fonologinen prosessointi) ovat pysyviä myös kompensoituneissa oppimisvaikeuksissa. (Ks. Wilson \& Lesaux 2001.)

Suomessa ongelmana ovat useimmiten lukemisen ja kirjoittamisen hitaus ja työläys sekä kirjoituksessa esiintyvät virheet. Pientä ryhmää aikuisista voidaan kuitenkin pitää käytännössä lukutaidottomina. Mitä vaativammalle koulutustasolle siirrytään, sitä suurempi merkitys on nopealla ja sujuvalla tekstin prosessoinnilla, jolloin hitaus ja työläys laajojen materiaalien lukemisessa ja tekstin tuottamisessa nousevat keskeisiksi ongelmiksi sekä opiskelussa että työelämässä. (Ahonen \& Haapasalo 2008.)

Oppimisvaikeuksien yhteydessä samat ongelmat, jotka tuottavat vaikeuksia omalla äidinkielellä, vaikeuttavat osin myös vieraan kielen opiskelua. Mitä suurempia vaikeudet ovat omalla äidinkielellä, sitä enemmän ne todennäköisesti vaikuttavat vieraaseen kieleen. Oppimisvaikeus vaikeuttaa joko suoraan tai epäsuorasti lukemista, kirjoittamista, kuuntelemista ja puhumista - siis kaikkia kielitaidon osa-alueita. (Crombie \& McColl 2001.)

Arviot oppimisvaikeuksien esiintymisestä vaihtelevat määritelmien mukaan. Kansainvälisen lukutaitotutkimuksen mukaan suomalaisista aikuisista noin 15 prosentilla on lukutaidossaan sellaisia vaikeuksia, jotka vaikeuttavat heidän oppimistaan, työllistymistään ja työntekoaan, rajoittavat heidän arkielämäänsä ja harrastuksiaan sekä vähentävät opiskeluhaluja ja aikuisopiskelua (Malin 2006, 19). Itseraportoituja vaikeuksia koulunkäynnissä tai oppimisessa on kokenut noin 16 prosenttia 18-29-vuotiaista. Lukemisen vaikeuksia raportoi viisi prosenttia, kirjoittamisen vaikeuksia kolme prosenttia ja matematiikan ja kielten vaikeuksia kuusi prosenttia. (Lavikainen 2005, 38.) Jyväskylän yliopiston pitkittäistutkimuksessa on arvioitu, että noin kolmella sadasta on aikuisiällä diagnosoitavissa oleva suvussa esiintyvä lukivaikeus. Tutkimusaineiston mukaan vähintään kuusi prosenttia kokee haitallisia vaikutuksia lukemisessa tai kirjoittamisessa. (Leinonen 1997, 23.) Kansainvälisesti lukivaikeuden esiintyvyydeksi arvioidaan viisi prosenttia (Frith 1999).
Oppimisvaikeuksien kohdalla ajateltiin pitkään, että niitä esiintyisi miehillä naisia useammin. Oppimisvaikeudet näyttäisivät olevan miehillä yleisempiä, mutta yhdeksi syyksi on esitetty myös naisten alidiagnosointia. Naisilla, jotka saavat oppimisvaikeusdiagnoosin koulussa, on keskimääräistä vaikeampi oppimisvaikeus (Vogel 1990). Suvuittain esiintyvää dysleksiaa arvioidaan esiintyvän yhtä paljon sekä naisilla että miehillä (esim. Shaywitz \& Shaywitz 2003). Vaikka oppimisvaikeuksia arvioidaan esiintyvän yhtä yleisesti sekä miehillä että naisilla, on naissukupuoli tulkittu suojaavaksi tekijäksi lukemisen ja kirjoittamisen yhteydessä (Berninger ym. 2008).

Oppimisvaikeudet on yhdistetty monenlaisiin sosiaalisiin ongelmiin. Tutkimuksissa on raportoitu jatko-opiskelumahdollisuuksien kaventumisesta, keskimääräistä matalammasta koulutustasosta ja muuta väestöä korkeammasta työttömyydestä (esimerkiksi Holopainen \& Savolainen 2005, Lavikainen ym. 2006, Ingvar ym. 1995). Samoin erilaisia itsetuntoja mielenterveysongelmia esiintyy usein oppimisvaikeuksien yhteydessä erityisesti naisilla (esimerkiksi Holopainen \& Savolainen 2006, Riddick ym. 1999, Wilson ym. 2009). Suurta osaa aikuisten oppimisvaikeuksista pidetään alitunnistamattomina ja -hoidettuina. Osalla oppimisvaikeudet on tunnistettu lapsena, mutta tukitoimet ovat jääneet vähäisiksi. On myös joukko, joiden vaikeudet ovat jääneet täysin tunnistamatta ja ilman tukitoimia. (Gerber 2005; Kasler \& Fawcett 2009, 202.) Oppimisvaikeuksien vaikutusten on myös arvioitu lisääntyvän työelämän vaatimusten kasvaessa.

\section{UUTTA TIETOA TUKITARPEISTA}

Opi oppimaan -projektiin hakeutuneista asiakkaista naisia oli 73 prosenttia ja miehiä 27 prosenttia. Sukupuolijakauma vastaa pitkälti aikaisempia kokemuksia aikuisten oppimisvaikeuksiin liittyvistä tukipalveluista (esimerkiksi Ala-Kauhaluoma ym. 2008). Asiakkaat olivat iältään 16-63-vuotiaita keski-iän ollessa 37 vuotta. Asiakkaat edustivat kaikkia koulutusasteita, mutta tyypillisimmin joko perusastetta (25\%) tai ammattikoulutusta (31\%). Yleisin elämäntilanne oli työssäkäynti (41 \%) tai opiskelu (31\%). Lähes puolet asiakkaista kuvasi myös jonkinasteista tyytymättö- 


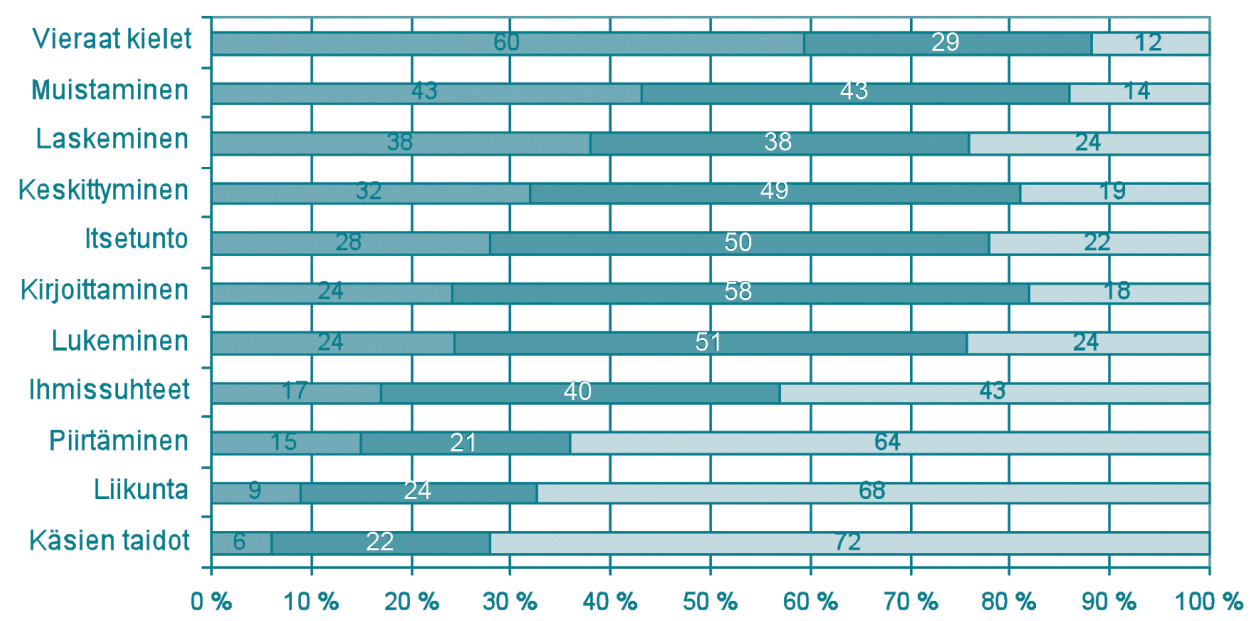

Suuria vaikeuksia $\square$ Lieviä vaikeuksia $\square$ Ei vaikeuksia

Kuva 1. Koetut vaikeudet aikuisena (\%) $(n=131)$.

myyttä työhönsä tai opiskeluun sekä toimeentuloonsa. Monella olikin taustalla jonkinlainen murroskohta opiskelussa tai työelämässä, esimerkiksi toive alan vaihtamisesta ja uuden opiskelun aloittamisesta.

Asiakkaista 62 prosenttia ei ollut oman ilmoituksensa mukaan saanut aikaisemmin tukipalveluita oppimisvaikeuksiinsa. Tukipalveluiden saaminen ajoittuu lähes yksinomaan perus- tai kansakouluun, sillä vain neljä prosenttia vastaajista arvioi saaneensa tukipalveluita aikuisuudessa. Lähes puolet (49\%) oli itse havainnut oppimisvaikeutensa. Naisista (56\%) suurempi määrä on itse havainnut oppimisvaikeutensa miehiin (29\%) verrattuna. Miehistä hieman yli puolella vaikeudet oli havaittu koulussa, kun taas naisilla luku on vajaa kolmannes (28\%). Tilanne on sama myös tukipalveluiden suhteen: naisista 70 prosenttia ei ole saanut aikaisemmin tukipalveluita, kun taas miehillä luku on 41 prosenttia. Myös iällä oli vaikutusta, sillä tukipalvelujen saaminen oli vähäisempää, mitä vanhemmasta asiakkaasta oli kyse. Nuorimmasta ikäluokasta 70 prosenttia oli saanut tukea peruskoulussa, kun vanhimmassa ikäluokassa luku oli 12 prosenttia. Edellä mainitut erot olivat myös tilastollisesti merkitseviä $(\mathrm{p}<0,05)$.

Asiakkaille toteutetun alkukyselyn perusteella yli kaksi kolmasosaa koki vaikeuksia lukemisen ja kir- joittamisen lisäksi myös monilla muilla alueilla, kuten vieraissa kielissä, muistamisessa, laskemisessa, keskittymisessä ja itsetunnossa (kuva 1). Suurimpia vaikeuksia koettiin vieraissa kielissä.

Myös aiemmissa tutkimuksissa on todettu, että Suomessa monet kokevat oppimisvaikeuksien yhteydessä suurimpia vaikeuksia juuri vieraissa kielissä (Lehtola \& Lehto 2000; Ala-Kauhaluoma ym. 2008). Vaikeudet vieraissa kielissä koetaan sitä suurempina, mitä selkeämpi lukivaikeus on kyseessä (Nukari 2010, 35). Vaikeudet ovat myös sellaisia, joihin on vaikeampi saada apua tai löytää itse tehokkaita ratkaisuja ja joilla on usein merkitystä opiskeluvalintojen tekemisessä ja opintojen loppuun suorittamisessa. Oppimisvaikeuksien yhteydessä tyypillisiä muistivaikeuksia ovat puheen ja luetun muistaminen sekä esimerkiksi nimien ja kertotaulun muistaminen. Yllättäen itsetuntovaikeudet koetaan suurempina kuin lukemisen ja kirjoittamisen vaikeudet. Oppimisvaikeuksiin liittyykin usein erilaisia epäonnistumisen, ristiriidan ja jopa häpeän kokemuksia. Toisaalta lukemisen hitautta ei välttämättä koeta suurena ongelmana, jos osaa varata riittävästi aikaa tai on löytänyt muita lukemista helpottavia selviytymiskeinoja. (Haapasalo 2006; Korkeamäki 2010a, 48-61.) Alkukyselyssä tiedusteltiin myös, millaisia vai- 
kutuksia oppimisvaikeudella on ollut asiakkaiden elämänvalintoihin. Vastanneista 95 prosenttia koki oppimisvaikeuksilla olleen vaikutusta omiin elämänvalintoihin. Näistä 37 prosenttia koki oppimisvaikeuden vaikuttaneen omiin elämänvalintoihin paljon. Esimerkkeinä vaikutuksista elämänvalintoihin mainittiin opintojen keskeyttäminen, halun ja uskalluksen puuttuminen opiskelun aloittamisesta sekä alavalintaan ja opiskelutapaan liittyvät tekijät. Työelämän ulkopuolella olevista asiakkaista 57 prosenttia koki oppimisvaikeuksien vaikuttaneen omiin elämänvalintoihin paljon $(\mathrm{p}<0,011)$.

Kysyttäessä suhtautumista opiskeluun kaikkein kielteisimmin suhtautuvat työelämän ulkopuolella olevat naiset. Kaikkein myönteisemmin oppimiseen ja opiskeluun suhtautuvat työelämässä olevat miehet, mutta miesten kohdalla erot eivät olleet tilastollisesti merkitseviä. Työssä käyvistä ja opiskelevista asiakkaista yli puolet suhtautui opiskeluun ja oppimiseen pääasiassa myönteisesti oppimisvaikeuksista huolimatta. Tulosten perusteella olisikin tärkeää kiinnittää huomiota työelämän ulkopuolella olevien naisten opiskeluun ja oppimiseen liittyvään suhtautumiseen (ks. myös Rojewski 1999). Suhtautumista opiskeluun voidaan pitää yhtenä kouluttautumista tukevana asiana (Korkeamäki 2010a, 60).

Oppimisvaikeuksien koettiin häiritsevän itseä eniten tietyissä työtehtävissä, tiettyjen aineiden opinnoissa ja yleisissä opiskelutaidoissa (kuva 2). Asiakkaiden elämäntilanteella oli merkitystä: Työs- säkäyvistä 76 prosenttia koki oppimisvaikeuden häiritsevän tiettyjä työtehtäviä. Yleisiä opiskelutaitoja oppimisvaikeus häiritsi eniten opiskelijoilla (74 \%) ja työelämän ulkopuolella olevilla (66 \%). Myös ikääntyminen vaikutti vastauksiin, sillä oppimisvaikeus häiritsi työssä selviytymistä, työnhakua ja arjen asioita sitä enemmän, mitä vanhempi vastaaja oli. Kaikki edellä mainitut erot ovat tilastollisesti merkitseviä $(\mathrm{p}<0,05)$.

Työelämässä koettuja tyypillisiä vaikeuksia ovat vieraiden kielten ja vierasperäisten termien käyttöön liittyvät hankaluudet, työssä koetut keskeytykset ja lukemisen ja kirjoittamisen työläys. Kirjallisiin töihin tai uusien tehtävien perehdyttämiseen ei ole myöskään varattu riittävästi aikaa. Työpaikan palavereissa vaikeuksia voivat tuottaa puheen seuraaminen sekä kokouspöytäkirjan pitäminen. Opiskeluissa vaikeuksia tuottavat tyypillisimmin vieraiden kielten opinnot, lääkelaskut, muistiinpanojen tekeminen, luettavan materiaalin laajuus ja vaikeaselkoisuus sekä opinnäytetyöt. Arjen hankaluuksia tuottavat esimerkiksi erilaiset lomakkeet. (Ks. Korkeamäki 2010a, Nukari 2010; Haapasalo 2006.)

Opi oppimaan -hankkeen palveluilta toivottiin etukäteen eniten oman oppimisvaikeuden selvittämistä (79\%), tietoa omista oppimisvalmiuksista (76\%) sekäneuvojaja harjoituksia ongelmatilanteisiin (70\%). Hankkeen haastattelututkimuksessa ilmeni, että vaikka oppimisvaikeudet olisi tunnistettu lapsena ja niihin oli ollut tarjolla erityistä tukea, oma oppi-

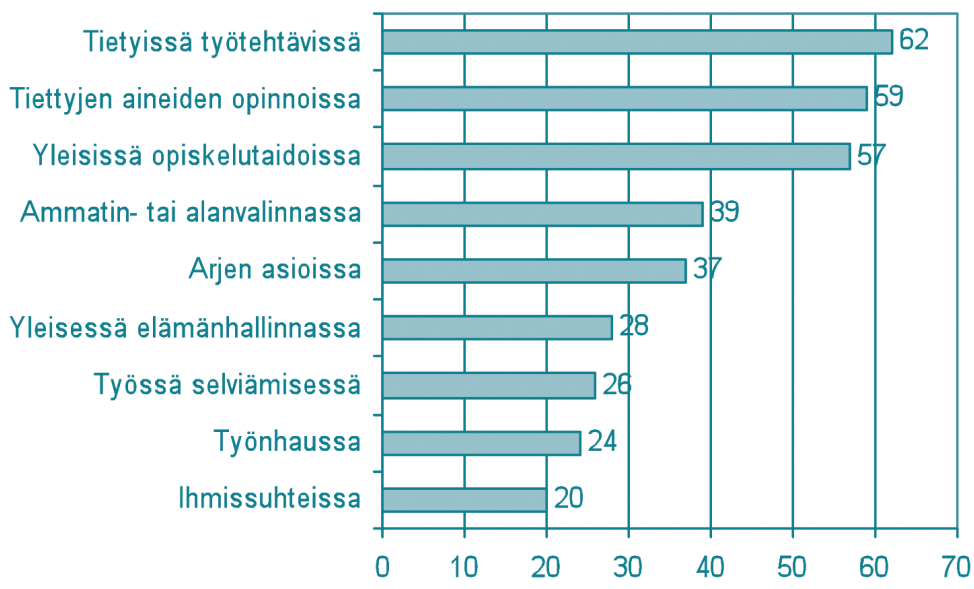

Kuva 2. Missä oppimisvaikeus häiritsee itseä eniten $(\%)$ ? $(n=138)$. 
Kuva 3. Mihin jatkossa tarvitsee tukea $(\%)$ ? $(n=75-79)$

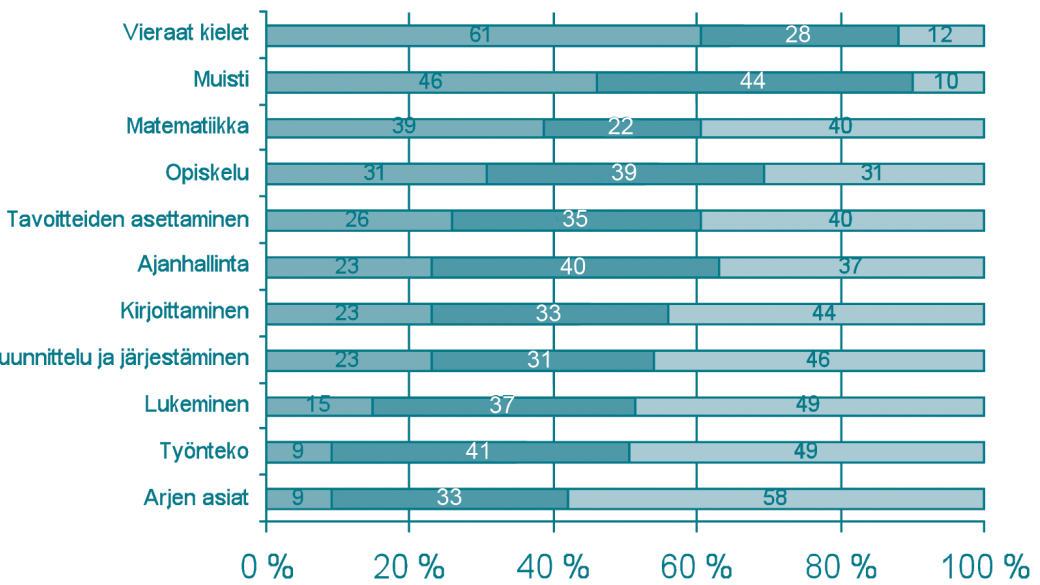

Paljon tukea $\square$ Jonkin verran tukea $\square$ Vähän tai ei lainkaan tukea misvaikeus saattoi silti jäädä itselle epäselväksi ja tukitoimet keskeneräisiksi. Haastateltavat toivat esille tarvetta selvittää vielä omia oppimistapojaan aikuisena ja löytää menestyksellisiä strategioita oppimisensa suhteen. Uusien kompensaatiokeinojen löytyminen erityisesti erilaisissa opiskelun ja työelämän murroksissa oli tärkeää. (Korkeamäki 2010a.)

\section{MIKÄ AUTTAA AIKUISTA?}

Asiakkailla toteutetun seurantakyselyn mukaan hankkeen tukipalveluihin osallistumisen vaikutukset painottuvat erilaisiin psykososiaalisiin tekijöihin akateemisten taitojen sijaan. Näitä on myös pidetty tärkeänä aikuisten ohjauksessa (esim. Ahonen \& Haapasalo 2008, Shaywitz \& Shaywitz 2003).

Asiakkaat raportoivat muun muassa itsetuntemuksen paranemisesta ja oppimisvaikeuden hyväksymisestä, joita pidetään tärkeinä oppimisvaikeuksiin liittyvinä suojaavina tekijöinä (Goldberg ym. 2003). Hankkeen toiminnalla kyettiin myös vaikuttamaan asiakkaiden käsityksiin omista oppimisvaikeuksista. Akateemisten taitojen parantuminen painottui miehillä naisia enemmän, sillä useampi mies (57\%) arvioi lukevansa ja/tai kirjoittavansa enemmän kuin ennen naisiin (27\%) verrattuna. Mitä useampaan hankkeen palveluun asiakas osallistui, sitä useammin hän koki tietävänsä riittävästi oppimisvaikeuksista ja tehneensä muutoksia omiin opiskelu- ja työskentelytapoihin. Erot olivat tilastollisesti merkitseviä $(\mathrm{p}<0,05)$.
Kysyttäessä tuen tarpeesta hankkeen toimintaan osallistumisen jälkeen puolet vastanneista kokee tarvitsevansa jatkossa vain vähän tai ei lainkaan tukea. Paljon ulkopuolista tukea ilmoittaa tarvitsevansa 13 prosenttia vastaajista. Työelämän ulkopuolella vastaushetkellä olevista 38 prosenttia ilmoittaa kuitenkin tarvitsevansa paljon tukea oppimisvaikeuksien kanssa selviytymiseen. Vähiten ulkopuolista tukea tarvitsevat jatkossa työssäkäyvät, joista 69 prosenttia kokee tarvitsevansa jatkossa vain vähän tai ei lainkaan ulkopuolista tukea. Erot ovat tilastollisesti merkitseviä $(p<0,000)$. Tukea kaivataan jatkossakin eniten vaikeuksia tuottaviin asioihin (kuva 3).

Hankkeen yhteydessä tehdyssä haastattelututkimuksessa (Korkeamäki 2010a) nousi vahvasti esille aikuisuuden monenlaiset merkitykset oppimisvaikeuksien suhteen. Aikuisena koettiin olevan vähemmän suorituspaineita kuin kouluaikoina. Työelämässä ei tarvinnut jatkuvasti suorittaa, oppia uutta tai olla arvioitavana, vaan asioita pystyi tekemään enemmän omalla tahdilla. Tätä onkin pidetty yhtenä syynä siihen, miksi oppimisvaikeuksien on nähty vähenevän aikuisuudessa (Goldberg ym. 2003; Paananen 2006, 96). Aikuistuminen siis helpottaa joitakin asioita, mutta saattaa myös tehdä asioita vaikeammiksi. Esimerkiksi aikuisena järkevän selityksen löytyminen omille vaikeuksille oli tärkeämpää ja oppimisvaikeuksien tunnistaminen ja diagnoosi koettiin usein helpottavana. Henkilökohtaisella tasolla aikuisuus 
vaikutti kovempiin vaatimuksiin oppimisen suhteen. Aikuisopiskelun haasteita olivat opiskelun, työn ja perhe-elämän yhteensovittaminen. Opiskelun työläys saattaa rajoittaa vapaa-aikaa. Osa aikuisopiskelijoista aloittaa opinnot pitkän tauon jälkeen, mikä vaikeuttaa opiskelua.

Tutkimuksessa nousi esille nuoruus ja aikuisuus merkittävänä ajanjaksona, jolloin opiskelusta oli saatu itsenäisempi ote ja opintomenestys oli parantunut. Aikuisopiskelussa oli paremmin mahdollisuuksia hyödyntää omia vahvuuksia. Opiskelu oli muuttanut luonnettaan, ja aikuisten kokemuksia arvostettiin. Myös opettajalla saattoi olla merkitystä opiskelun tukemisessa, sillä hyvä opettaja sai pohtimaan omaa oppimista ja siinä koettuja vaikeuksia. Oppimisen kannalta oli tärkeää, että opettaja auttoi myös kokonaisuuden hahmottamisessa. Myönteiset kokemukset tuen saamisesta aikuiskoulutuksessa liittyivät hyvään vuorovaikutukseen opiskelijoiden ja opettajien välillä. Tällöin opettajat miettivät vaihtoehtoisia suoritustapoja tai huomioivat oppimisvaikeudet arvioinnin yhteydessä.

\section{OPPIMISVAIKEUKSIEN HUOMIOINTI AIKUISKOULUTUKSESSA}

Aikuisten ohjauksessa ja tuessa on tärkeää hyödyntää heidän omia kiinnostuksiaan ja aikaisempia tietojaan. Olennaista on rohkaista tavoitteiden asettamiseen, opettaa muististrategioita, hyödyntää uuden teknologian mahdollisuuksia sekä tukea organisointikykyä. Uusien strategioiden opettelu ja niiden käyttöönotto vaativat aikaa. Uuden tiedon määrän tulee olla hallittavissa. Kuntoutuksessa on myös tärkeää painottaa kognitiivisten taitojen ohella itsetunnon tukemista ja omien vahvuuksien tunnistamista. Vertaistuki ja positiiviset roolimallit ovat usein hyödyllisiä. (Pannucci \& Walmsley 2007, Ahonen \& Haapasalo 2008, Reiterä-Paajanen \& Haapasalo 2010, Saarelainen \& Haapasalo 2010.)

Uuden näkökulman aikuiskoulutukseen tarjoaa esteettömän opetuksen kehittäminen, jonka mukaisesti pyritään ennakoimaan ja huomioimaan opiskelussa eri syistä ilmenevät esteet. Lisäaika, tietokoneen käyttö, nauhurit, äänikirjat, luentojäsennykset, tuutorointi, vaihtoehdot kirjallisille kokeille ja rauhallinen koetila ovat tavanomaisimmat opiskelujärjestelyt (Shaywitz \& Shaywitz 2003). Uuden teknologian hyödyntämisestä on saatu lupaavia tuloksia aikuisilla, samoin kuin vieraiden kielten vaikeuksissa (Service 2008).

Aikaisempaa tutkimusta ja tietoa suomalaisten aikuisten kokemuksista ja tukitarpeista on tällä hetkellä vähän saatavilla. Tässä kuvattu aineisto heijastaa pitkälti oppimisvaikeutensa tunnistaneiden ja tukea oma-aloitteisesti hakeneiden kokemuksia. Tätä näkökulmaa voidaan pitää tärkeänä, koska aikuisilla tuen saaminen perustuu omaehtoiseen oppimisvaikeudesta kertomiseen ja omaan aktiivisuuteen. Vaikka projektin aineisto kuvaa ainakin osin valikoitunutta asiakaskuntaa, pystytään sen avulla avaamaan eri elämäntilanteessa olevien aikuisten kokemuksia ja tuentarpeita. Tuloksista on hyötyä aikuisten palveluiden toteuttamiselle ja jatkokehittämiselle.

Opi oppimaan -hankkeen kokemuksen mukaan kohderyhmiä, joiden on vaikea nykyisin löytää tarvittavaa tukea, ovat työssä olevat, jotka suunnittelevat alan vaihtoa ja harkitsevat uusia opiskeluja. Myös työelämän ulkopuolella eri syistä olevien oppimisvaikeudet olisi huomioitava paremmin. Vaikka aikuisopiskelun tukea kehitetään jatkuvasti, ovat tukikäytännöt vielä vaihtelevia. Tukea olisi hyvä tarjota myös omien oppimisvaikeuksien tunnistamiseen. Esimerkiksi tietokoneavusteisten itsearviointi- ja seulontamenetelmien kehittämisestä on saatu hyviä kokemuksia (Kasler \& Fawcett 2009; Singleton 2009).

Aikuiset kokevat suurimpia vaikeuksia vieraissa kielissä. Aikuisille olisi tärkeää arvioida omaa kielitaitoaan ja saada vinkkejä kielenopiskelun aloittamiseen. Myönteiset kokemukset kielenopiskelusta ovat tärkeitä. Oman ryhmänsä muodostavat ne, jotka on aikoinaan kokonaan vapautettu kieliopinnoista. Oppimisvaikeudet olisi hyvä sisällyttää yhtenä osana opiskelutaitoja käsitteleville kursseille, vaikka kurssit suunnattaisiin laajemmalle joukolle. Vertaistuen kokemus ei ole itsestään selvä oppimisvaikeuksien kohdalla, joten vertaistukea tarjoavat kurssit ovat hyödyllisiä kokemuksen jakamisen, tiedon saamisen ja uusien opiskelukeinojen saamiseksi (Korkeamäki 2010b). 
Tutkintotavoitteisen opiskelun ohella vapaa sivistystyö tarjoaa hyvän mahdollisuuden tukea aikuisten oppimisvaikeuksia, sillä tukea tarvitaan erityisesti opiskeluvalmiuksiin ja vieraisiin kieliin. Myös tietoteknisten valmiuksien kehittäminen olisi monelle oppimisvaikeuksia kokevalle hyödyksi. Oppimisen esteettömyyden kannalta tärkeää ovat monipuoliset opetusmenetelmät, opetuksen selkeys ja riittävän rauhallinen etenemistahti. Osa aikuisista kokee, että heillä on oppimisvaikeuksiensa vuoksi puutteellinen yleissivistys. Kysyntää voisi olla esimerkiksi erilaisille historiakursseille, joilla voi hyödyntää olemassa olevia ääni- ja selkokirjoja. Tällaiset opinnot sopisivat luontevasti myös maahanmuuttajille.

Tärkeää on, että oppimisvaikeuksia kokevat ihmiset löytävät tarvittavat palvelut ja että heillä on taloudelliset mahdollisuudet osallistua opiskeluun. Yksi vaihtoehto madaltaa opiskelukynnystä voisi olla tietoiskut opiskelumahdollisuuksista ja erilaiset lyhytkurssit. Opintosetelillä pystytään kohdentamaan kursseja aikuisten oppimisvaikeuksiin. Vapaan sivistystyön toimijoiden oppimisvaikeuksiin suunnatut kurssit lisäisivät myös alueellista tasa-arvoa.

Aikuisopiskelun saavutettavuutta ja esteettömyyttä tulisi pohtia monesta eri näkökulmasta. Koulutuksen kehittäminen esteettömäksi hyödyttää kaikkia opiskelijoita. Esteettömyyden kehittämisen ohella tarvitaan myös kohdennettua tukea, joka huomioi juuri oppimisen erityisvaikeudet (myös Mellard \& Patterson 2008). Elinikäisen oppimisen näkökulmasta on tärkeää, että ihmisille tarjotaan tukea ja uusia mahdollisuuksia oppimiseen myös aikuisena.

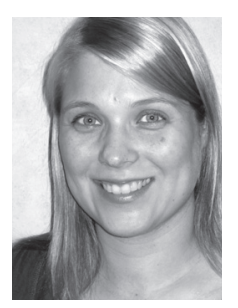

Johanna Korkeamäki

VTM, projektitutkija,

Kuntoutusalan tutkimus-ja

kehittämiskeskus,

Kuntoutussäätiö, Helsinki

\section{LÄHTEET}

Ahonen, T. \& Haapasalo, S. (2008). Oppimisvaikeudet. Teoksessa Rissanen P, Kallanranta T \& Suikkanen A (toim.) Kuntoutus. Helsinki: Duodecim.

Ala-Kauhaluoma, M., Laurila, H. \& Haapasalo, S. (2008). Oppimisvaikeudet tukipalvelun haasteena. Lukineuvola-hankkeen arviointitutkimus. Helsinki: Kuntoutussäätiön työselosteita 35/2008.

Berninger, V., Nielsen, K., Abbott, R., Wijsman, E. \& Raskind, W. (2008). Gender differences in severity of writing and reading disabilities. Journal of School Psychology 46, 151-172.

Crombie, M. \& McColl, H. (2001). Dyslexia and the teaching of modern foreign languages. Teoksessa Peer L. \& Reid G. (toim.) Dyslexia. Successful inclusion in the secondary school. London: David Fulton Publishers, 54-63.

Frith, U. (1999). Paradoxes in the definition of dyslexia. Dyslexia 5 (4), 192-214.

Gerber, P (2005). Low-literate adults with learning disabilities. A review of the literature. Thalamus 2005. 42-54.

Goldberg, R., Higgins, E., Raskind, M. \& Herman, K. (2003). Predictors of success in individuals with learning disabilities: A qualitative analysis of a 20year longitudinal study. Learning Disabilities Research and Practice 18 (4), 222-236.

Haapasalo, S. (2006). Erilainen oppijuus haasteena ja voimavarana. Aikuiskasvatus 26 (1), 32-38.

Holopainen, L., Aro, M. \& Savolainen, H. (2008). Mitä ovat lukivaikeudet? Teoksessa Kairaluoma, L., Ahonen, T., Aro, M., Kakkuri, I., Laakso, K., Peltonen. M. \& Wennström, K. (toim.) Lukemalla ja tekemällä. Opettajan opas lukivaikeudesta ammatillisille oppilaitoksille. Jyväskylä: Niilo Mäki Instituutti.

Holopainen, L. \& Savolainen, H. (2005). Erityisopetus ja oppimisvaikeudet. Teoksessa Korkeakoski E (toim.) Koulutuksen perusturva ja oppimisen tuki perusopetuksessa. Syventävät artikkelit. Jyväskylä: Koulutuksen arviointineuvosto.

Holopainen, L. \& Savolainen, H. (2006). Lukivaikeudet ja koettu psyykkinen hyvinvointi toisen asteen opintojen alussa. Kasvatus 37 (5), 463-474.

Ingvar, D., Lindgren, M. \& Stenmark, R. (1995). Arbetslöshet och dyslexi. Arbetsmarknad \& Arbetsliv 1 (1), 45-56.

Kasler, J. \& Fawcett, A. (2009). Screening for learning disabilities in young adult career counselling. Work 32 (2), 201-210.

Korkeamäki, J. (2010a). Aikuisten oppimisvaikeudet. Näkökulmia selviytymiseen. Kuntoutussäätiön tutkimuksia 83/2010. Helsinki: Kuntoutussäätiö. 
Korkeamäki, J. (2010b). Ryhmätoiminnan arviointia. Teoksessa Saarelainen, AL. \& Haapasalo, S. (toim.) (2010). Ryhmästä voimaa aikuisten oppimisvaikeuksiin. Helsinki: Kuntoutussäätiö.

Korkeamäki, J., Reuter, A. \& Haapasalo, S. (2010). Aikuisten oppimisvaikeuksien tunnistus, arviointi ja kuntoutus. Opi oppimaan -projektin toimeenpano ja tulokset. Kuntoutussäätiön työselosteita 40/2010. Helsinki: Kuntoutussäätiö.

Lavikainen, H., Koskinen, S., Aro, H., Kestilä, L., Lyytinen, H., Martelin, T., Pensola, T., Rahkonen, O. \& Aromaa A. (2006). Kouluvaikeuksien yleisyys ja yhteydet aikuisiän elämäntilanteeseen ja koettuun terveyteen. Yhteiskuntapolitiikka 71 (4), 402-410.

Lehtola, R. \& Lehto, J. (2000). Assessing dyslexia in Finnish high-school students: a pilot study. European Journal of Special Education 15 (3), 255-263.

Leinonen, S. (1997). Elämän vaihtoehdot kapeutuvat. Teoksessa Strandén K (toim.) Erilainen oppija. Oppimisvaikeuksien kokeminen, syyt, esiintyvyys ja kuntoutus. Jyväskylä: Hero/Stakes.

Malin, A. (2006). Suomessakin on heikkoja lukijoita. Teoksessa Leskelä L \& Virtanen H (toim.) Toisin sanoen. Selkokielen teoriaa ja käytäntöä. Helsinki: Kehitysvammaliitto, 15-31.

Mellard, D. \& Patterson, M. (2008). Contrasting adult literacy learners with and without specific learning disabilities. Remedial and Special Education 29 (3). 133-144.

Nukari, J. (2010). Aikuisten oppimisvaikeuksien psykologinen arviointi. Kuntoutussäätiön työselosteita 39/2010. Helsinki: Kuntoutussäätiö.

Paananen, S. (2006). Dysleksia, identiteetti ja biografinen oppiminen. Dysleksia aikuisen elämänkerronnassa. Acta Universitatis Lapponiensis 107. Rovaniemi: Lapin yliopisto.

Pannucci, L. \& Walmsley, S. (2007). Supporting learningdisabled adults in literacy. Journal of Adolescents \& Adult literacy 50 (7), 540-546.

Reiterä-Paajanen, U. \& Haapasalo, S. (2010). Oppimisvalmennusta aikuisten kuntoutusmuotona. Helsinki: Kuntoutussäätiö.

Riddick, B., Sterling, C., Farmer, M. \& Morgan, S. (1999). Self-esteem and anxiety in the educational histories of adult Dyslexics students. Dyslexia 5, 227-248.

Rojewski, J. (1999). Occupational and educational aspirations and attainment of young adults with and without LD 2 years after high school completion. Journal of Learning Disabilities 32 (6), 533-552.
Saarelainen, AL. \& Haapasalo, S. (toim.) (2010). Ryhmästä voimaa aikuisten oppimisvaikeuksiin. Helsinki: Kuntoutussäätiö.

Service, E. (2008). Mitä tutkimus kertoo vieraan kielen oppimisvaikeuksista. Teoksessa Kairaluoma, L., Ahonen, T., Aro, M., Kakkuri, I., Laakso, K., Peltonen. M. \& Wennström, K. (toim.) Lukemalla ja tekemällä. Opettajan opas lukivaikeudesta ammatillisille oppilaitoksille. Jyväskylä: Niilo Mäki Instituutti.

Shaywitz, S. \& Shaywitz, B. (2003). The science of reading and dyslexia. Journal of Aapos 7 (3), 158-166.

Singleton, C., Horne, J. \& Simmons, F. (2009). Computerised screening for dyslexia in adults. Journal of Research in Reading 32 (1), 137-152.

Vogel, S. (1990). Gender differences in intelligence, language, visual-motor abilities and academic achievement in students with learning disabilities. A review of the literature. Journal of Learning Disabilities 23 (1), 44-52.

Wilson, A., Deri Armstrong, C., Furrie, A. \& Walcot, E. (2009). The mental health of Canadians with selfreported learning disabilities. Journal of Learning Disabilities 42 (1), 24-40.

Wilson, A. \& Lesaux, N. (2001). Persistence of phonological processing deficits in college students with dyslexia who have age-appropriate reading skills. Journal of Learning Disabilities 34 (5), 394-400. 